\title{
WATER FOR FLORIDA CITIES
}

$\frac{10}{20}$ and (4. $($ (n) .
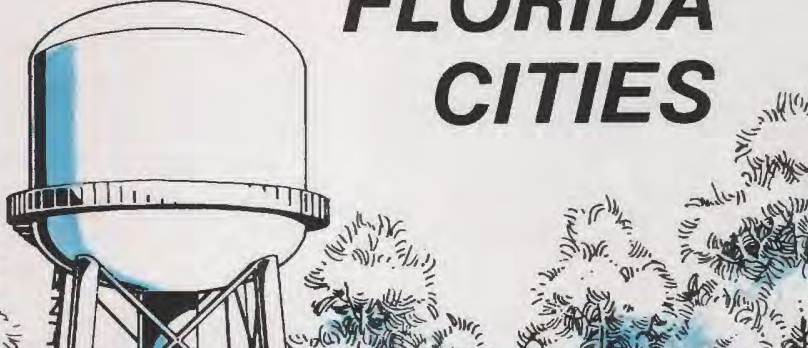

Y. II 1 ( (1) D

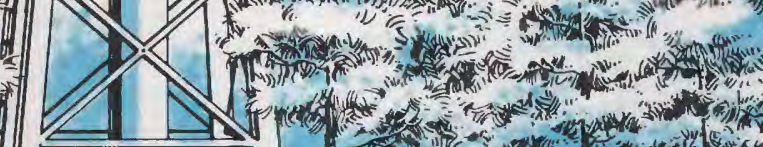

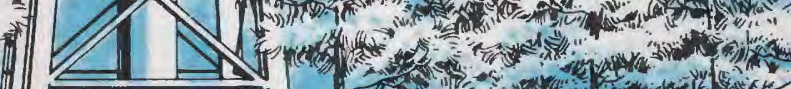
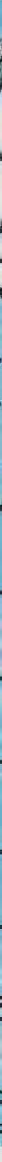

Water-Resources Investigations Report 86-4122 U.S. Department of the Interior/Geolgical Survey 


\section{WATER FOR FLORIDA CITIES}

By G. Warren Leve

and Clyde S. Conover

Water is one of Florida's most valuable resources. Each year millions of residents and tourists enjoy the recreational opportunities and esthetics afforded by thousands of miles of ocean and marine waterways along the coasts. Though scenic and plentiful, this water cannot furnish Florida with drinking water, or irrigate crops, or supply most industries, because it is salty. In most cases, freshwater supplies come from extensive beds of porous rocks beneath the ground called aquifers and from a few freshwater lakes, streams, and reservoirs.

All freshwater in Florida comes from rainfall. Normally, between 52 and 64 inches of rain falls each year except in the Keys which receive less than 40 inches. Once rain reaches the ground, three things commonly occur: (1) A part runs off into lakes, streams, and reservoirs as surface water, eventually discharging into the Gulf of Mexico or into the Atlantic Ocean; (2) a part seeps into the ground and is stored in aquifers as ground water, eventually returning to the surface as seepage, spring flow, or pumpage from wells; and (3) a large part returns to the atmosphere by evaporation from soils, lakes, streams, and the oceans, and by transpiration from plants and trees. Evaporation and transpiration, collectively called evapotranspiration, eventually condenses and again falls on the surface of the Earth as rainfall. This continuous movement of water through and over the Earth and between the Earth and atmosphere is called the hydrologic cycle.

Recently, the demand for freshwater has risen because of increasing population and expanding industrial and agricultural development. The natural hydrologic cycle is being stressed, particularly in large urban, industrial, and agricultural areas. Of paramount interest are the questions: Where do Florida cities get their water, and what is the outlook for a continuing supply of freshwater? In general terms, the sources of water tapped for supply by Florida's cities are described herein. Common questions asked relative to source, supply, suitability, permanence, and other

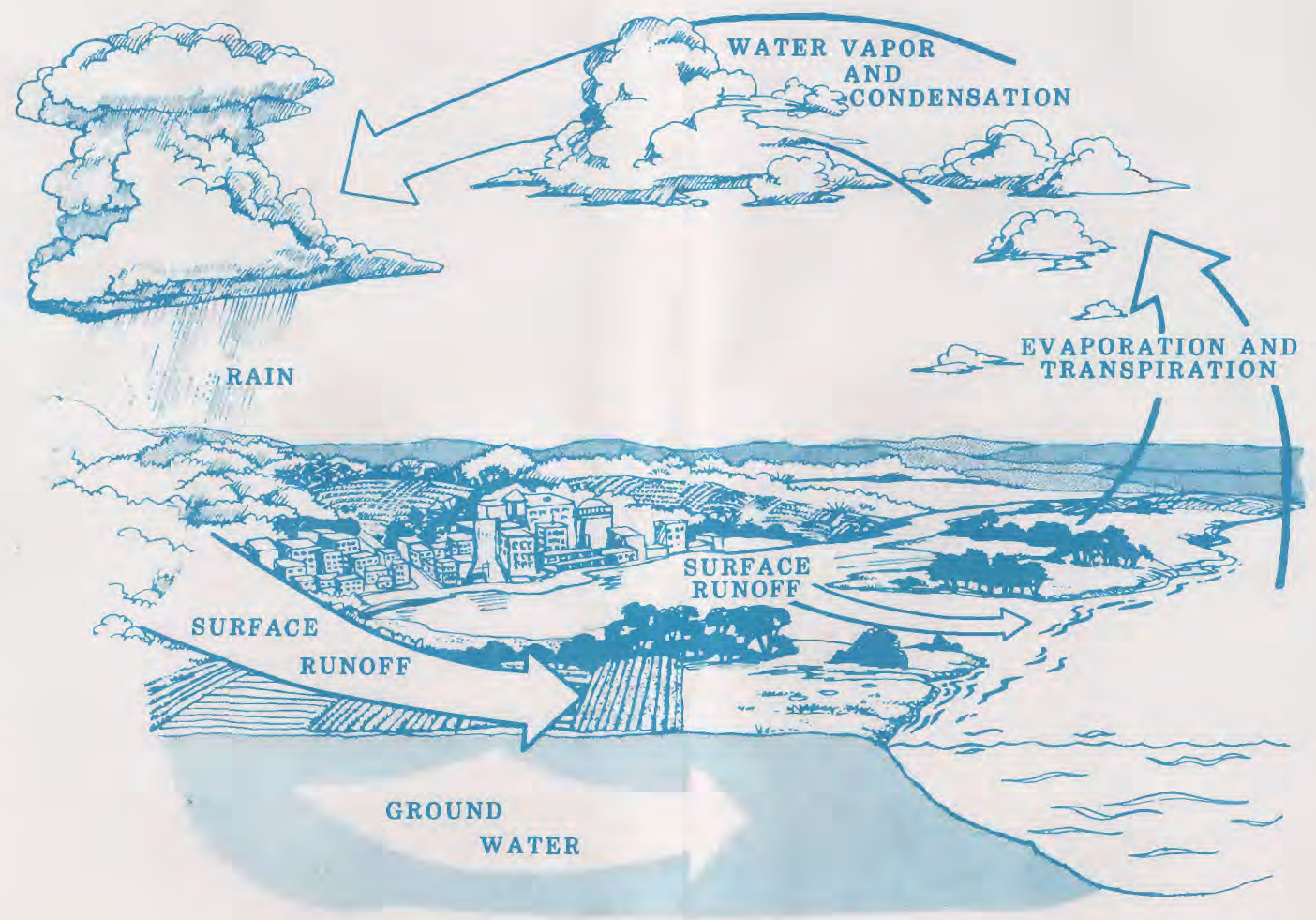




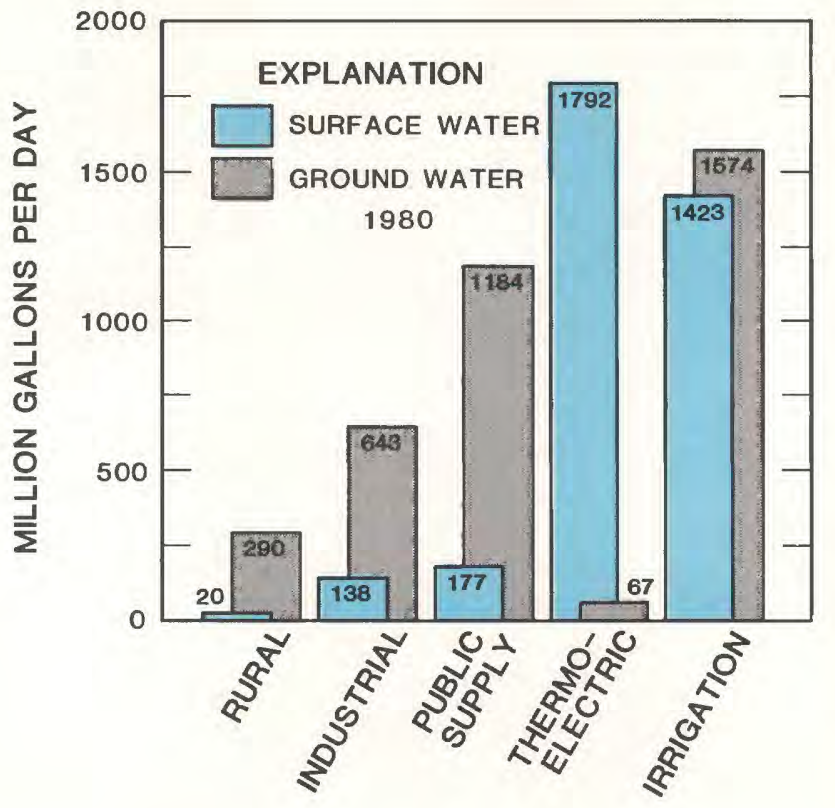

aspects related to city water supplies are answered briefly. For those desiring more specific information, a list of selected references and a list of State and Federal water resource agencies is included.

\section{HOW IS WATER USED?}

In 1980, more than 2.66 trillion gallons of freshwater, about $7,300 \mathrm{Mgal} / \mathrm{d}$, were used in Florida. Slightly more than half was ground water and the remainder was surface water. About 66 percent of the water used was returned to surface streams and aquifers; the remaining 34 percent was not returned to the system because of evaporation and transpiration.

By far the largest use of freshwater was for irrigation and more than half of this water was ground water. The second largest use was for thermoelectric power generation; however, about 96 percent of this water came from surface streams and was returned to the streams after use. The third largest use was for public supply for county, municipal, and privately owned water utilities; public supply ranked second in the use of ground water. A lesser amount of water was used by self-supplied industries and the least amount was used for rural (domestic and livestock) supplies.

The amount of water used for public supply is increasing, primarily because of population growth. 


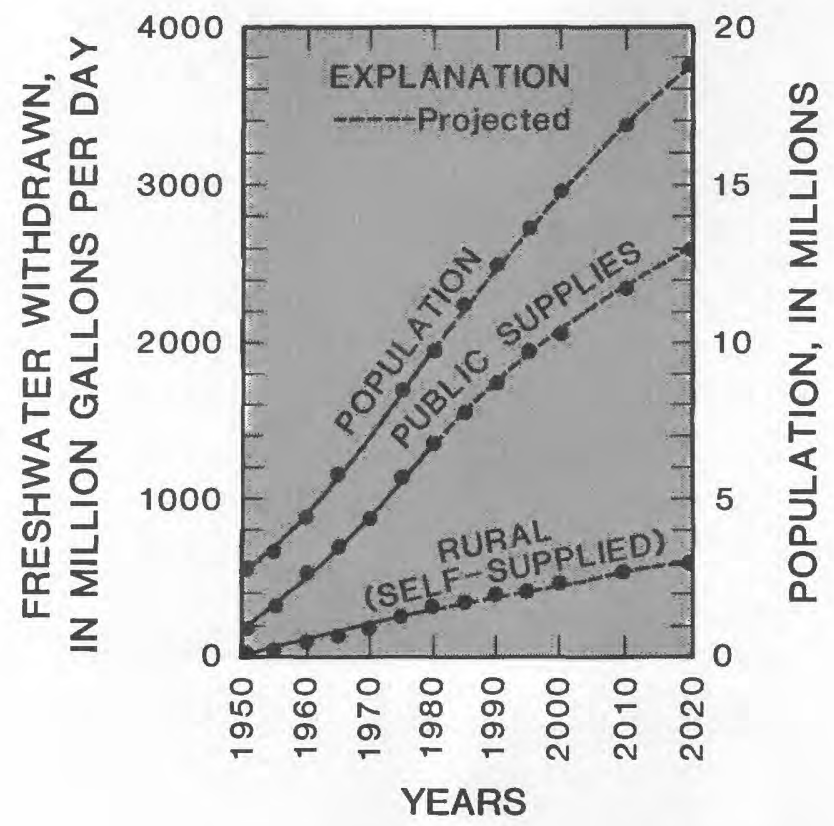

Between 1950 and 1980, the population of Florida increased from about 2.7 to $9.7 \mathrm{million}$ and the amount of water used for public supply increased from 170 to about 1,400 Mgal/d. The total amount of freshwater withdrawn for all uses increased from less than 1,000 to about 7,300 Mgal/d during the same period. Projections for Florida for the year 2020 show a 93 percent growth in population from 1980 and an increase in use of water for public supply to $2,600 \mathrm{Mgal} / \mathrm{d}$. However, future total water use is not as predictable as that for public supply because of changing uses and various water conservation measures being undertaken by major categories of use.

\section{HOW DOES WATER OCCUR, AND WHAT LIMITS ITS USE?}

Water occurs in lakes, ponds, streams, marshes, and swamps, in manmade surface impoundments (reservoirs), and in aquifers throughout Florida. Although there are about 7,800 freshwater lakes in Florida and more than 1,700 surface streams, only a few large water-supply systems obtain all or part of their water from surfacewater sources. There are several reasons for this:

$\square$ Most of the major streams and freshwater lakes are in central and northern Florida, away from major centers of population. To use this water, long aqueducts or canals would be needed. 
$\square$ During periods of deficient rainfall, many of the lakes and streams are low or dry. Because the land is relatively low and flat, reservoirs can be constructed in only a few areas. Florida has 9 freshwater reservoirs with surface areas larger than 6 square miles. Only one large reservoir, Deer Point Lake near Panama City, was constructed primarily for water supply. The other large reservoirs were constructed for hydroelectric power generation and for water regulation.

$\square$ All the large rivers, except the Kissimmee, empty into the Gulf of Mexico or into the Atlantic Ocean. During high tides, storms, and periods of low freshwater discharge, salty water can move upstream for many miles. Consequently, water in the lower reaches of these rivers often is not potable. For example, the St. Johns River contains salty water 60 to 80 miles upstream under certain high tide and low-flow conditions.

Good quality ground water is readily available in adequate quantities at relatively low cost nearly everywhere in Florida's extensive aquifers, except on the coasts where both ground water and surface water may be salty.

Treatment of ground water is relatively simple and cheap as contrasted with surface water. The quantity and quality of ground water is relatively stable, whereas that of surface water is susceptible to large short-term and seasonal changes.

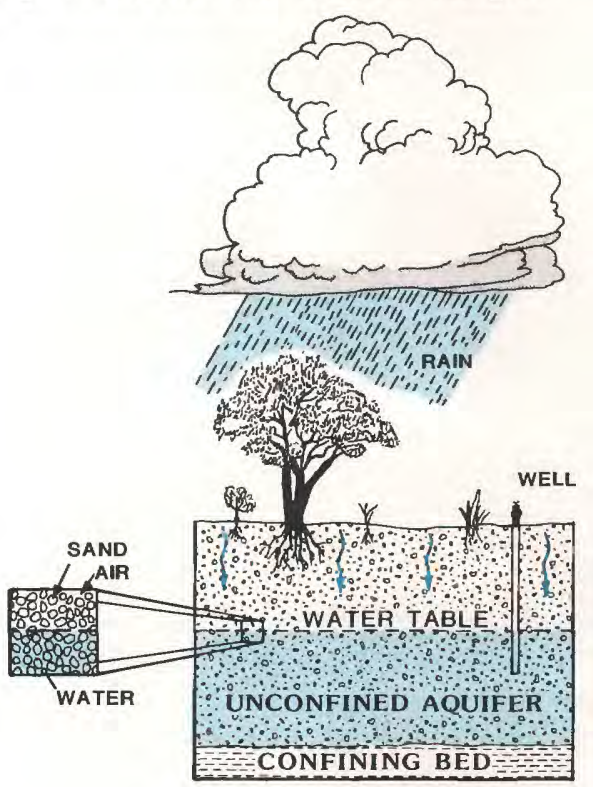


About 90 percent of the population of Florida is served by ground water and about 87 percent of publicsupply withdrawals are ground water. Use of ground water for public supply and other withdrawal uses reduces competition for the various inherent uses of surface water in Florida's unique environment.

Florida is underlain by extensive aquifers composed of sand, shel1, and limestone-dolomite deposited 2 to 60 million years ago when Florida was covered by the sea. Ground water is stored in the pore spaces of aquifers much like water in a gigantic sponge. The water moves through the interconnected pore spaces to wells, springs, and other points of discharge. Some rocks such as clay, silt, and dense dolomite are not considered to be aquifers because they contain pore spaces that are either too small or not sufficiently interconnected to allow significant amounts of water to move through them. These rocks are called confining beds.

Ground water occurs under unconfined and confined conditions in Florida. Unconfined ground water occurs in surficial aquifers not covered by confining beds and can be replenished directly by local rainfall. Water enters the aquifer much as water enters a sand-filled bucket. Adding water to the bucket raises the level of water in the sand. The upper surface of water in an unconfined aquifer is called the water table.

Confined ground water is generally replenished or recharged in areas where the aquifers are close to the

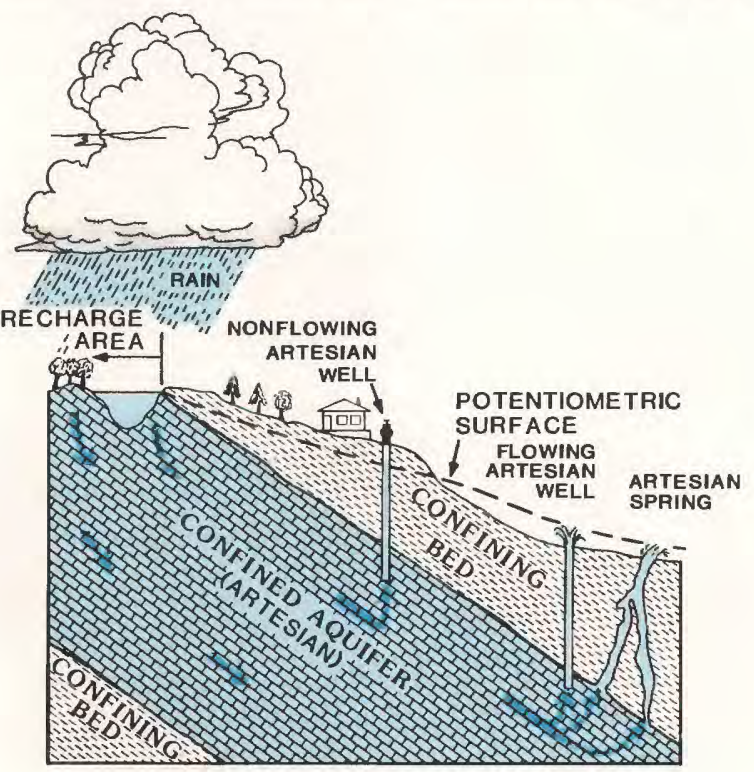


1and surface or where the confining beds are thin or missing. Infiltrating rainwater, surface water, or ground water from the overlying unconfined aquifer enters the confined aquifer. Water that enters the aquifer moves toward areas of discharge. The water is restricted from moving upward by the overlying confining beds and is held under artesian pressure within the aquifer. An imaginary surface defined by the level of water in tightly cased wells that tap a confined aquifer is called the potentiometric surface. Wells that tap a confined aquifer are called artesian wells. In areas where the potentiometric surface of the aquifer is above land surface, water will flow from the wel1. Flowing wells are common in many of the coastal regions of Florida,

In some areas, the confining beds are broken by faults and fractures, or have been removed by erosion, and the water flows at the surface as springs. Florida has more than 300 known springs; a large part of the water in the Suwannee, Santa Fe, Oklawaha, and other rivers in the state comes from springs.

\section{HOW IS WATER OBTAINED?}

Ground water is obtained from aquifers by wells. Each municipality or water-supply system that uses ground water has one or more wells; large cities need many wells to provide sufficient water supplies. These wells commonly are arranged in clusters or well fields. Some large cities may have several well fields, each with perhaps 10 to 20 wells.

The type of well used depends on the geologic properties of the aquifer. In all wells, the loose uncon-

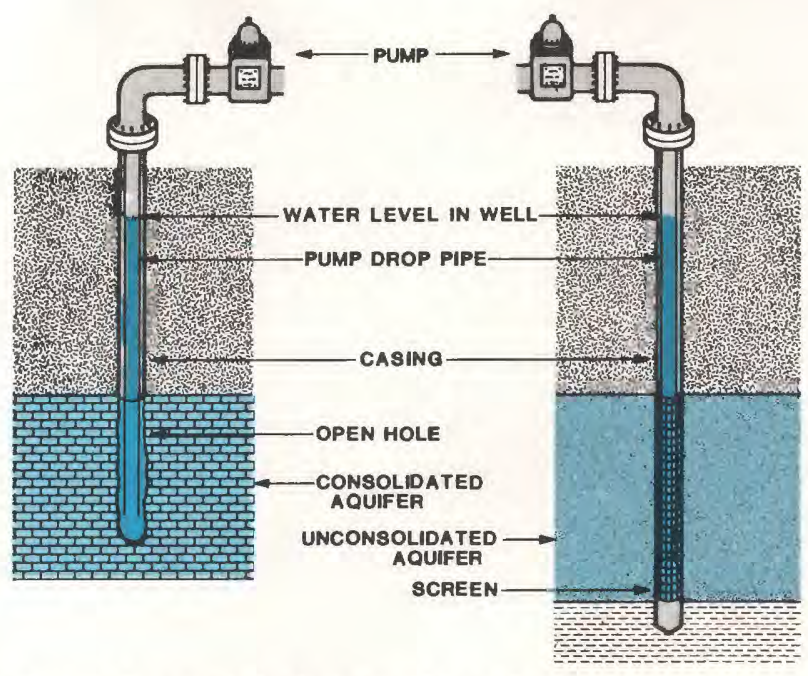

solidated material that overlies the aquifers is prevented from filling the well bore by installing pipe called casing. If the aquifer is consolidated rock such as limestone-dolomite, the well is completed by drilling an open hole below the casing to allow water to enter the well from the aquifer. If the aquifer consists of loose, unconsolidated material such as sand, the part below the casing is fitted with a screen that allows water to enter the well from the aquifer, but keeps out the unconsolidated material. The depths of municipal wells range from less than 20 feet in the unconfined aquifer in southwest Florida to about 1,500 feet in the confined aquifer underlying northeast Florida. The diameters of most municipal wells range from 8 to 24 inches.

Water from each well is pumped (or allowed to flow to the surface if it is a flowing well) and is treated.

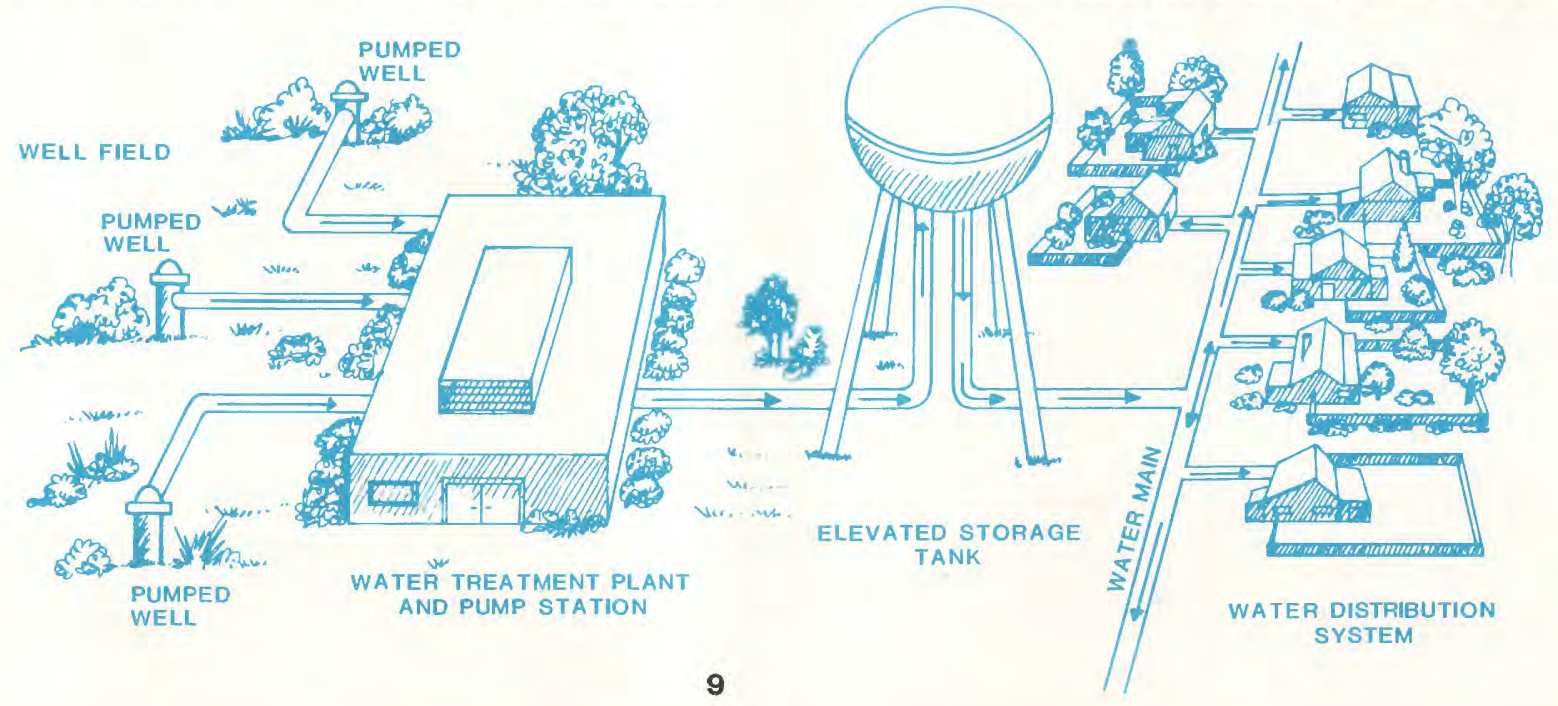


Treatment ranges from simple disinfection (chlorination, to remove biological impurities) to complex water softening and desalination (to change or reduce the concentration of chemicals in the water).

The scarcity of good quality drinking water in many areas, particularly near the coasts and inland in south Florida, has made desalting a feasible means of water treatment for public supply. Desalted ground water is the source for more than 85 public-supply facilities. The capacities of the systems range from about 1,000 gal/d for small subdivisions to about $5 \mathrm{Mgal} / \mathrm{d}$ for Cape Coral and Sarasota and $10 \mathrm{Mgal} / \mathrm{d}$ for Key West.

Surface water is obtained from natural or regulated lakes or from reservoirs by pumping to a treatment plant. Treatment of surface water generally is more complex than for ground water because of the variable amounts and character of suspended and dissolved material. Treatment may include chlorination; coagulation; sedimentation and filtration; softening; flocculation; pH control; stabilization; and taste, odor, and algae control. After treatment, water is pumped to ground level or elevated water storage reservoirs where it is then pumped or flows by gravity through the water distribution system to the individual water users.

Because of the variable quantity and quality of surface water and the lack of good impoundments, only about 25 municipalities use surface water, some of which also use ground water.

\section{WHAT IS THE QUALITY OF WATER?}

Rainwater is relatively free of particulate and dissolved chemical substances. However, as rainwater runs off into lakes and streams as overland flow or seeps into aquifers, it dissolves chemical substances on the land surface and in the soil and rocks and mixes with other water in lakes or streams or with ground water in the aquifer. The amount and chemical composition of substances dissolved in the water depend upon the type and solubility of surface materials, soil, and rock with which the water comes in contact, the length of time it stays in contact, and the amount and composition of the water with which it mixes. Normally, ground water contains higher concentrations of dissolved constituents than surface water because it comes in contact with soil and rocks for longer periods of time as it moves slowly through the ground. However, this is not true everywhere in Florida; for example, in recharge areas where the water first enters the ground 
or in areas where the rocks in the aquifer are very insoluble, the ground water may have lower concentrations of dissolved substances than surface water. In other areas where surface water is largely derived from ground water (springs) or has mixed with brackish surface water, it may have the same or higher concentrations of dissolved substances than ground water.

The concentration of dissolved solids is a measure of the amount of chemical substances in solution in water and is useful as an index of water quality. If the dissolved-solids concentration exceeds $500 \mathrm{milli-}$ grams per liter (mg/L), which is about $1 \mathrm{lb}$ of solid material in 2,000 lbs of water, the water is generally considered undesirable to drink. However, in many parts of the United States, people routinely drink water that contains more than $500 \mathrm{mg} / \mathrm{L}$ dissolved solids where less mineralized water is not available. In Florida, most of the water used for municipal supplies contains less than $500 \mathrm{mg} / \mathrm{L}$ dissolved solids and practically all of the water contains less than $1,000 \mathrm{mg} / \mathrm{L}$, which is still considered to be freshwater.

Another measure of the quality of water is its hardness which is determined by the amount of calcium and magnesium in solution. The degree of hardness is expressed as equivalent amounts of calcium carbonate which is the principal mineral in limestone. Water is classified as soft if hardness is less than $60 \mathrm{mg} / \mathrm{L}$, moderately hard if between $60 \mathrm{mg} / \mathrm{L}$ and $120 \mathrm{mg} / \mathrm{L}$, hard if between $120 \mathrm{mg} / \mathrm{L}$ and $180 \mathrm{mg} / \mathrm{L}$, and very hard if it contains more than $180 \mathrm{mg} / \mathrm{L}$. Most of the water used for public supplies in Florida is classified as hard to very hard and, if untreated, will generally leave a scale on plumbing fixtures and cooking utensils.

As a result of the enactment of Florida's Water Quality Assurance Act of 1983, considerable attention is now being paid to the issue of ground-water contamination. Of particular concern are organic chemicals, such as pesticides and industrial solvents, and trace metals such as chromium, lead, and mercury. These chemicals can be harmful even in low concentrations. Results of sampling in 1984 of the untreated ground water used for public supply in 108 communities in Florida indicated only one chemical in one community that exceeded the State's standards for drinking water. Because of the slow rate of ground-water movement and the naturally occurring attenuation processes, including dilution, dispersion, sorption, ion exchange, and chemical precipitation, ground-water contamination 
tends to be localized and confined to distances of less than a few miles from the contaminant source.

Overall, the quality of water used for municipal supplies in Florida, with minimum treatment, meets the criteria established by the State and by the U.S. Environmental Protection Agency for safe water.

\section{WHAT ARE THE SOURCES OF WATER FOR FLORIDA CITIES?}

Most of the water for Florida's cities is ground water. It comes from three major sources: the Floridan aquifer system, the Biscayne aquifer, and the sandand-gravel aquifer. Other unamed surficial aquifers and intermediate aquifers are important locally as sources of ground-water supplies. The principal aquifer used for municipal supplies in each area of the State, and locations of cited cities using ground water, are depicted.

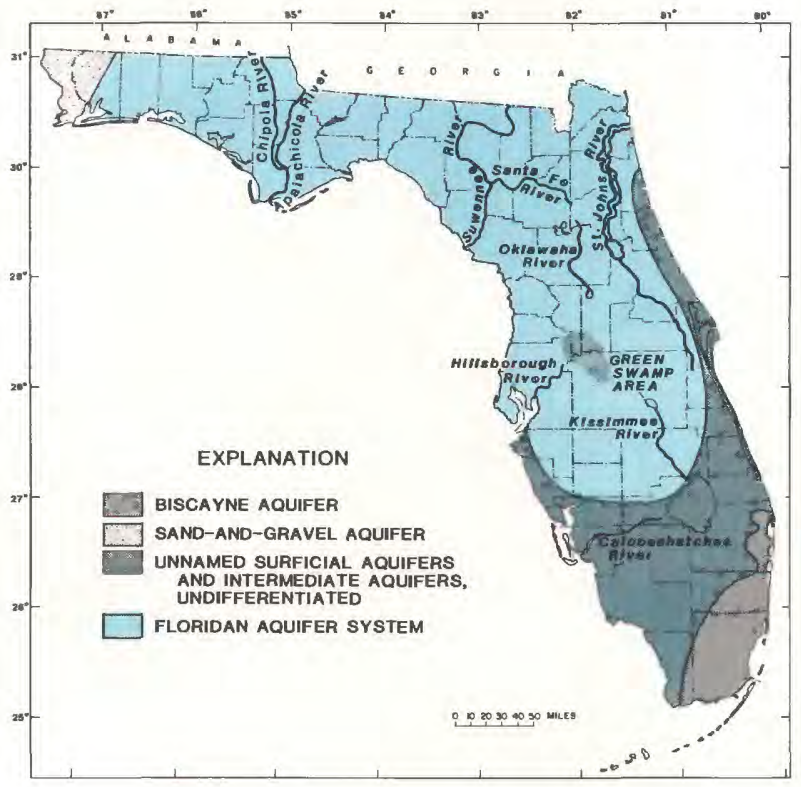

Surface water is used as a source of supply for about 25 municipalities--generally where local ground water is of poor quality. The principal cities supplied, in whole or in part, by surface water are, in descending order of population served, Tampa, Melbourne, West Palm Beach, Panama City, Fort Myers, Bradenton, Port Charlotte, and Belle Glade (see table). 


\begin{tabular}{|c|c|c|c|}
\hline \multirow[b]{2}{*}{ Municipality } & \multirow[b]{2}{*}{ County } & \multirow[b]{2}{*}{ Source } & $\begin{array}{l}\text { Approximate } \\
\text { percentage }\end{array}$ \\
\hline & & & $\begin{array}{l}\text { pplied from } \\
\text { urce cited }\end{array}$ \\
\hline Belle Glade ${ }^{1}$ & Palm Beach & Lake Okeechobee & 100 \\
\hline Bradenton & Manatee & $\begin{array}{l}\text { Braden \& Manatee } \\
\text { Rivers }\end{array}$ & 100 \\
\hline Bryant & Palm Beach & Lake Okeechobee & 100 \\
\hline Callaway & Bay & Deer Point Reservoir & 100 \\
\hline Clewiston & Hendry & Lake Okeechobee & 100 \\
\hline Fort Myers & Lee & Caloosahatchee River & 50 \\
\hline $\begin{array}{l}\text { Fort Myers } \\
\text { (suburban) }\end{array}$ & do. & do. & 100 \\
\hline Marcos Island & Collier & Limerock pit & 100 \\
\hline Melbourne & Brevard & Lake Washington & 100 \\
\hline $\begin{array}{l}\text { North Port } \\
\text { Charlotte }\end{array}$ & Sarasota & $\begin{array}{l}\text { Peace \& Myakka-Hatchee } \\
\text { Rivers \& Fordham } \\
\text { Waterway }\end{array}$ & 100 \\
\hline Okeechobee & Okeechobee & Lake Okeechobee & 100 \\
\hline Pahokee & Palm Beach & do. & 100 \\
\hline Palmetto & Manatee & Manatee River & 100 \\
\hline Panama City & Bay & Deer Point Reservoir & 100 \\
\hline $\begin{array}{l}\text { Panama City } \\
\text { Beach }\end{array}$ & do. & do. & 15 \\
\hline Port Charlotte & Charlotte & $\begin{array}{l}\text { Peace \& Myakka-Hatchee } \\
\text { Rivers \& Fordham } \\
\text { Waterway }\end{array}$ & 100 \\
\hline Port Saint Joe & Gulf & Chipola River & 100 \\
\hline Punta Gorda & Charlotte & $\begin{array}{l}\text { Shell and Prairie } \\
\text { Creeks }\end{array}$ & 100 \\
\hline Quincy & Gadsden & Quincy Creek & 100 \\
\hline Springfield & Bay & Deer Point Reservoir & 100 \\
\hline South Bay & Palm Beach & Lake Okeechobee & 100 \\
\hline Tampa & Hillsborough & Hillsborough River & 80 \\
\hline $\begin{array}{l}\text { West Palm } \\
\text { Beach }\end{array}$ & Palm Beach & $\begin{array}{l}\text { Lake Mangonia \& Clear } \\
\text { Lake }\end{array}$ & 100 \\
\hline
\end{tabular}

\footnotetext{
1 Includes other municipalities.
}

The productive Floridan aquifer system underlies all of Florida and supplies water to most of the cities in the central and northern parts of the State including Clearwater, Fort Walton Beach, Gainesville, Jacksonville, Lakeland, Ocala, Orlando, St. Petersburg, Tallahassee, and Tampa. The top of the aquifer is at or near land surface in north-central Florida and dips to more than 500 feet below land surface along the coast in northeastern Florida and to more than 1,000 feet below land surface in extreme southern and western Florida. Where it is near the surface, it is unconfined and recharged by local rainfall. In other areas, the aquifer is overlain by confining beds and is replenished somewhat indirectly through the overlying confining beds where the water table is above the potentiometric surface. 

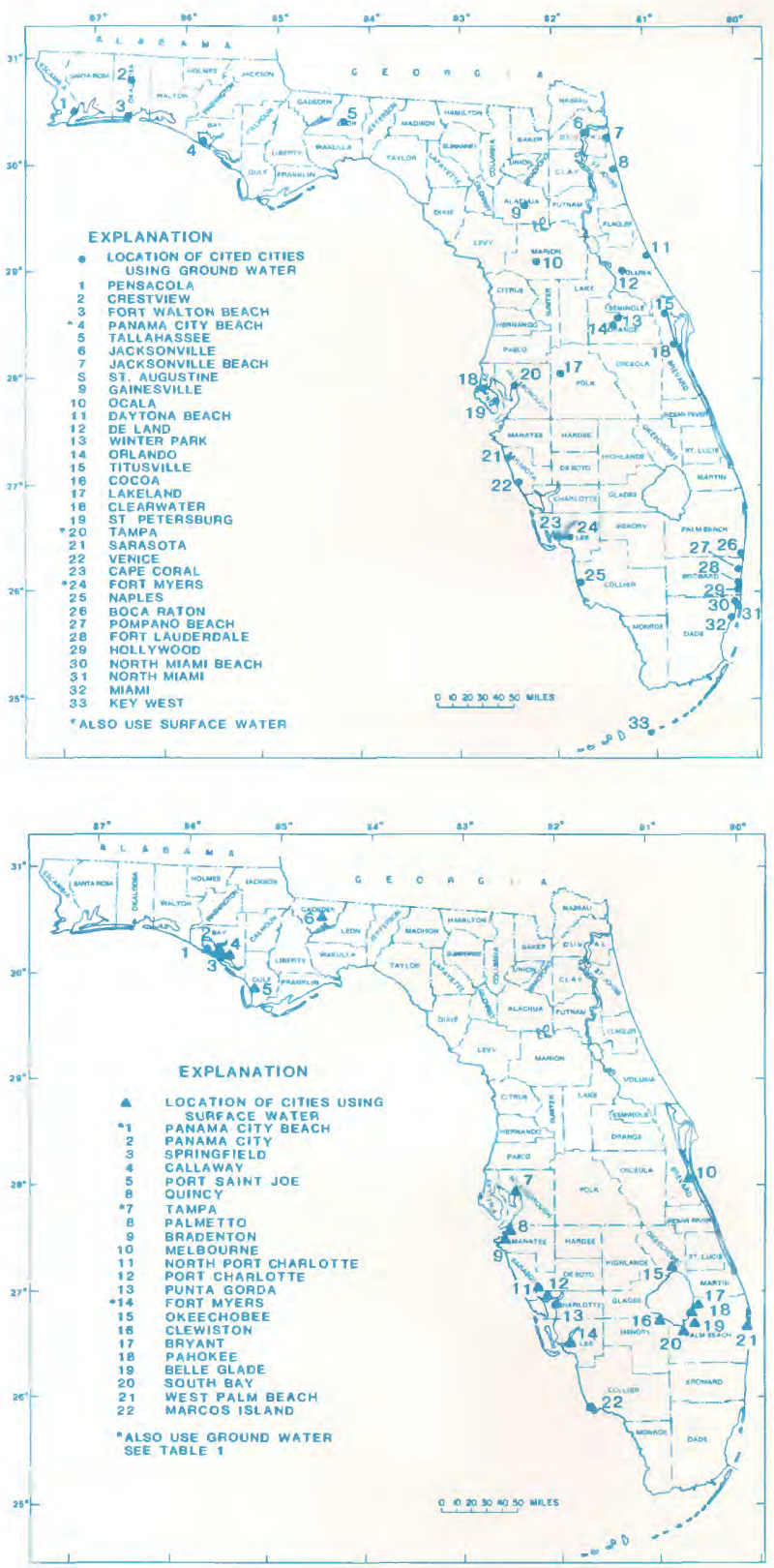

The Biscayne aquifer is virtually as productive as the Floridan aquifer system, but is restricted areally. It supplies water to most of the heavily populated areas in southeastern Florida including Fort Lauderdale, Hollywood, Miami, and Miami Beach. It lies directly below land surface and is recharged naturally by local rainfall and artificially by seepage from canals which transport water into southeastern Florida from Lake Okeechobee and the Water Conservation Areas. 
The sand-and-gravel aquifer supplies water to communities in extreme northwestern Florida, principally Pensacola. It is an unconfined aquifer and is recharged directly by local rainfall.

The unnamed surficial aquifers and intermediate aquifers consist of numerous, relatively thin, discontinuous aquifers that overlie the Floridan aquifer system in areas other than where the Biscayne or sandand-gravel aquifers occur. They are mostly used for small individual domestic supplies throughout the State and are only used for municipal supplies in areas where surface supplies are not readily available and where the Floridan aquifer system contains poor quality water (along the east coast from Palm Beach to St. Augustine and in a wide band across the State in the vicinity of Lake Okeechobee). Some of the larger municipalities supplied either entirely or partly by these aquifers are Fort Myers, Naples, St. Augustine, Titusville, and Sarasota. The surficial aquifers are unconfined, but the intermediate aquifers are confined.

\section{Southeast Florida (Miami-Fort Lauderdale)}

\section{Source of Supplies}

Practically all the municipal water supplies in southeast Florida come from the Biscayne aquifer. In 1980, about 20 regional, municipal, and private water utility companies pumped an average of $450 \mathrm{Mgal} / \mathrm{d}$ from the aquifer to supply about 2.25 million people in the incorporated and unincorporated areas in eastern Broward and Dade Counties. One of these utilities, the Florida Keys Aqueduct Authority, also supplied an average of $6 \mathrm{Mgal} / \mathrm{d}$ to the Florida Keys in Monroe County.

Water is obtained from wells that range from 30 to 190 feet in depth and 4 to 42 inches in diameter. Some of the smaller municipalities obtain all of their supplies from 3 or 4 wells located in one well field; larger municipalities may obtain their supplies from as many as 50 or 60 wells in several well fields. For example, in 1980 Dania, in southeastern Broward County with a population of about 11,800 people, pumped an average of $1.17 \mathrm{Mgal} / \mathrm{d}$ from 4 wells in one well field whereas Miami and adjacent unincorporated areas in Dade County, with a population of more than $1.16 \mathrm{million}$ people, pumped an average of $241 \mathrm{Mgal} / \mathrm{d}$ from about 60 wells in 6 well fields. 


\section{Water-Management Concerns and Practices}

The Biscayne aquifer is an unconfined aquifer and is recharged by local rainfall. The average rainfall is about 60 inches in southeast Florida; about two-thirds falls between June and October. During some winter months, there is practically no rainfall. Recharge to the aquifer is generally plentiful, or at times even excessive, during the rainy periods, but there are periods, particularly during winter and spring, when the aquifer receives no recharge. Pumpage from the aquifer during these dry periods is generally as great or greater than during the wet periods, and water levels decline.

Management of a dependable supply has been compounded in recent years because of rapid increases in population. Southeast Florida is one of the fastest growing areas in the Nation. Between 1940 and 1980 the population of Broward and Dade Counties increased from about 300,000 to more than 2.6 million ( 850 percent). This resulted in proportionate increases in the amount of water withdrawn from the Biscayne aquifer. The average daily pumpage of the Miami-Dade Water and Sewer Authority Department, which supplies water to Miami and adjacent areas, increased from $30 \mathrm{Mgal} / \mathrm{d}$ in 1940 to about $240 \mathrm{Mgal} / \mathrm{d}$ in 1980 . If this trend continues, the demands for water could eventually exceed the supply

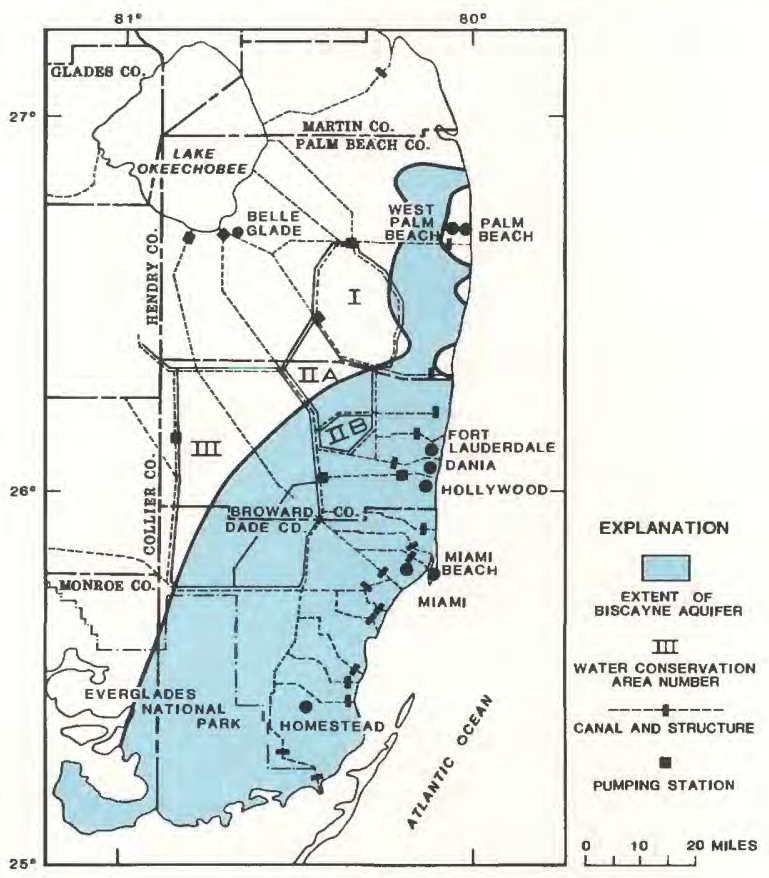


that is locally available in the aquifer and supplemental or more distant sources would have to be found.

There are also some concerns about water quality. Although the quality of water in the Biscayne aquifer is generally suitable for municipal supplies, there are some local problems in maintaining the water quality. The aquifer is close to the surface and is, therefore, highly susceptible to contamination by seepage from septic tanks, landfills, roads and parking lots, and other surface sources. Some contamination from surface sources has occurred in parts of southeast Florida, but thus far it has been localized.

The Biscayne aquifer is also susceptible to saltwater intrusion. Near the coast, salty water is present in the aquifer and in the tidal canals between the bay and the coastal control structures. During the rainy season, freshwater runs off into, and raises the water levels in, the canals and also recharges and raises the water levels in the aquifer. This pushes the salty water in the canals downstream toward the coast and in the aquifer, downward and seaward. During the dry season, runoff and recharge reduce or cease, water levels in the canals and the aquifer decline, and runoff to the ocean stops. Salty water then tends to move upstream in the canals and to move inland and upward in the coastal sections of the aquifer.

To offset the seasonal inequality of recharge to the aquifer, the water is carefully managed through a series of conservation areas and canals. During the rainy season, water is stored in the Conservation Areas behind dikes and control structures in western Broward and Dade Counties, and water in the agricultural and urban areas in eastern Broward and Dade Counties is drained into canals. Flow in the canals is regulated by control structures near the coast. During the rainy season, the coastal control structures are kept open and allow water in the canals to discharge into the ocean. This lowers the ground-water levels and prevents flooding. During the dry season, water is released from the Conservation Areas and flows through the canals to the vicinity of the well fields. Also during the dry season, the coastal control structures are closed to prevent water in the canals from discharging into the ocean. The water in the canals then seeps downward and recharges the aquifer. The closed coastal control structures maintain water levels in the aquifer at sufficient levels to prevent lateral and vertical movement of salty ground water and also to 
prevent saltwater from moving upstream in the canals and infiltrating into the aquifer during the dry season.

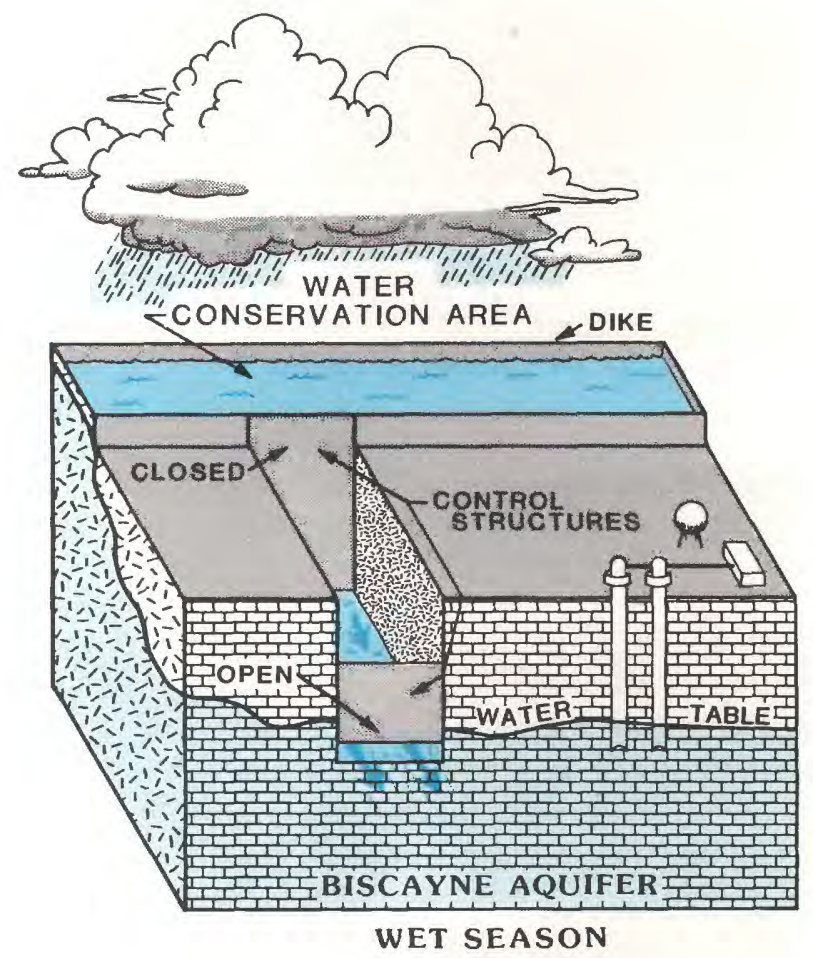

WATER

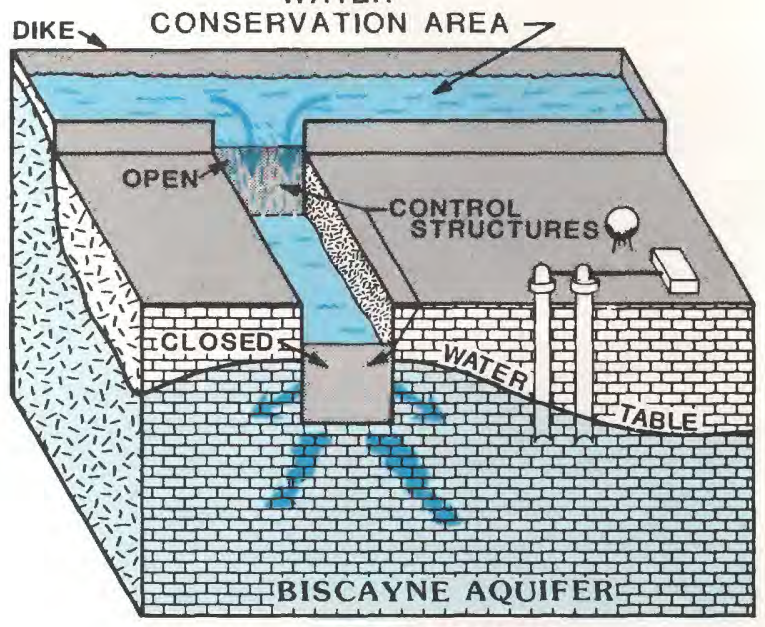


Problems arise when there is deficient rainfall during the rainy season or when there is a prolonged dry season. During these periods, water in the Conservation Areas is inadequate to meet the demands for water; water levels decline, and saltwater can intrude into the aquifer. This has occurred several times in the past 20 years, and some well fields close to the coast have been abandoned because of saltwater intrusion. During these dry periods, water managers have had to place restrictions on the use of water.

\section{West-Central Florida (Tampa-St. Petersburg)}

\section{Source of Supplies}

Municipal water supplies in west-central Florida are obtained from ground- and surface-water sources. Until recently, the Hillsborough River was the only source of municipal water for Tampa. The river originates in southeast Pasco County, near the Green Swamp area, and flows southwestward into Hillsborough Bay, an arm of Tampa Bay. Much of the flow is from springs that discharge water from the Floridan aquifer system into the river. The municipal supplies are obtained from Hillsborough Reservoir that is formed by a dam about 7 miles upstream from the river mouth. Within the last few years, water from the river has been augmented by water from the Floridan aquifer system. A well field northeast of Tampa now supplies about 20 percent of Tampa's municipal water supply. In 1980 , about $50 \mathrm{Mgal} / \mathrm{d}$ were pumped from the Hillsborough River and about $15 \mathrm{Mgal} / \mathrm{d}$ (23 percent) were pumped from the well field. Many coastal communities south of the Tampa-St. Petersburg areas, in Manatee, Sarasota, Charlotte, and Lee Counties, obtain all or part of their water supply from local surface-water sources.

St. Petersburg, Clearwater, and the other municipalities in Hillsborough, Pasco, and Pinellas Counties obtain all of their water supplies from the Floridan aquifer system. The top of the aquifer ranges from 15 to 250 feet below the surface. Wells range in depth from about 100 feet in western Pasco and northwestern Pinellas Counties to more than 1,000 feet in eastern Hillsborough County; however, the depth of most of the wells is between 300 and 500 feet. About 20 well fields exist within the three counties. Many of the well fields are at some distance from the municipalities served. Some of the smaller well fields contain four or five wells and supply an average of less than $1 \mathrm{Mgal} / \mathrm{d}$. Some of the large well fields contain 30 to 50 wells and supply an average of about $30 \mathrm{Mgal} / \mathrm{d}$. 


\section{Water-Management Concerns and Practices}

West-central Florida has a large supply of water suitable in quality for many uses but the increasing demands for water have resulted in some water-

management problems. Between 1960 and 1980 both the population and water use in Hillsborough, Pasco, and Pinellas Counties nearly doubled. Municipal pumpage by Tampa and St. Petersburg increased from about $47 \mathrm{Mgal} / \mathrm{d}$ to about $103 \mathrm{Mgal} / \mathrm{d}$ within the 20 -year period.

Because of the increased need for water, most municipalities were forced to obtain new or supplemental sources of water. In order to supply the increased demands for Tampa, water from a large spring was diverted into the Hillsborough Reservoir and, as the demands continued to increase, water had to be obtained from wells tapping the Floridan aquifer system. New well fields have also been established to supply water to the other rapidly urbanized areas throughout westcentral Florida.

As additional wells were drilled into the Floridan aquifer system and withdrawals from the aquifer increased, artesian pressures gradually declined, particularly in the vicinity of the well fields. In the coastal regions of Pinellas County, this decline resulted in saltwater intrusion. Many of the existing well fields near the coast became contaminated by saltwater and had to be abandoned or used only to obtain limited amounts of water. New well fields were established, in some cases many miles inland in Hillsborough and Pasco Counties, to supply sufficient potable water to these coastal communities.

The decline in artesian pressure in the Floridan aquifer system has caused other problems. Many lakes and ponds in west-central Florida are directly or indirectly connected to the aquifer and lake levels are lowered by ground-water pumpage from nearby well fields. In other areas, large cavities in the upper part of the Floridan aquifer system are filled with water. As artesian pressures decline, the rocks above the cavities collapse causing sinkholes to form at the surface. Formation of sinkholes is frequently triggered by drought or by lowered artesian pressure caused by artificial lowering of artesian pressure caused by pumping wells. 
Water resources in west-central Florida have been managed by local and State regulatory agencies for more than 20 years. Permits must be obtained for construction of most larger wells and for the amount of water that can be pumped from each well. The drilling of wells and pumpage from the Floridan aquifer system is carefully controlled in problem areas to prevent saltwater intrusion and excessive declines in artesian pressure.

In addition to controlling discharge, watermanagement practices also increase the amount of recharge to the Floridan aquifer system. A flood detention area, similar to water conservation areas in southeast Florida, has been constructed in a recharge area in the vicinity of Tampa's municipal well field. The area has been diked to retain excess surface water during the rainy season. The retention of surface water increases downward infiltration of water and the amount of recharge to the aquifer.

\section{East-Central Florida (Orlando) Source of Supplies}

The Floridan aquifer system is the principal source of municipal water throughout east-central Florida. It underlies the entire area at depths ranging from about 50 feet below land surface in southwestern Lake County to between 150 and 350 feet below the surface along the coast in eastern Volusia and Brevard Counties. There are several high-rate recharge areas to the aquifer. The most notable are the sandy hills in Lake, Seminole, and western Orange Counties. Another is in western Volusia County in the vicinity of De Land. In these areas, the aquifer is at or near the surface and the overlying confining beds are thin or missing or breached by sinkholes. The confining beds become thicker as the aquifer dips toward the coast and then little or no recharge occurs.

Most municipalities in Lake, Orange, Seminole, Volusia, and Brevard Counties each obtain their water supplies from wells drilled into the Floridan aquifer system. The wells range in depth from about 90 to 1,500 feet. However, along some of the coastal regions in Volusia and Brevard Counties the aquifer contains saline water and some municipalities must find other sources of supply. For example, Titusville obtains its 
water from wells drilled into the surficial aquifer and Melbourne uses surface water from Lake Washington, about 10 miles northwest on the St. Johns River. Cocoa obtains water from the Floridan aquifer system, but the wells fields are several miles west of the coast and in eastern Orange County.

Orlando, the largest city in east-central Florida, obtains its water from more than 20 wells drilled into two separate depth intervals in the Floridan aquifer system. The upper interval extends from about 100 to 600 feet below land surface, and the lower interval extends from about 1,100 to 1,500 feet below the surface. Only three municipal supply wells produce water from the upper interval. The rest are cased through the upper interval and produce water only from the lower interval. In 1980, the city utility pumped an average of $50 \mathrm{Mgal} / \mathrm{d}$ to supply about 262,000 people.

\section{Water-Management Concerns and Practices}

The rate of withdrawals of water from the Floridan aquifer system in east-central Florida is increasing and there is some concern that withdrawals will eventually exceed the capacity of the system. Water levels have declined in many areas and some local saltwater intrusion has occurred. However, as water levels decline in the recharge areas, increasing amounts of surface water and shallow ground water are diverted downward to recharge the Floridan aquifer system. As long as recharge areas are protected from excessive development so that rainfall can enter the ground in these areas, additional induced recharge to the Floridan should accompany increased withdrawals. The increase in recharge to the Floridan aquifer system will likely come, in part, at the expense of declining lake levels and reduction in wetland areas.

Another water-management concern is the presence of drainage wells. Within a 16-mile radius of downtown Orlando, at least 400 drainage wells have been drilled into the Floridan aquifer system. These wells were drilled to control lake levels and drain excess stormwater from the surface. In one sense, these wells serve a useful purpose as they help to artificially recharge the aquifer. However, they have the potential to contaminate the water in the aquifer. Water from the surface enters the aquifer directly through the drainage wells and mixes with the freshwater in the 
aquifer. Most of the drainage wells are drilled into the upper part of the aquifer, above the interval where most of the municipal wells obtain water and, so far, there has been no noticeable degradation of the quality of municipal water supplies.

\section{Northeast Florida (Jacksonville)}

\section{Source of Supplies}

Most of the municipal water supplies in northeast Florida are obtained from the Floridan aquifer system. The aquifer underlies the entire northeastern part of the State at depths ranging from about 200 to 500 feet.

The principal recharge area for the aquifer in northeast Flprida is the lake region in southwestern Clay and northwestern Putnam Counties. In this area, the top of the aquifer is about 200 feet below land surface but the overlying confining beds are thin or breached by numerous sinkhole lakes which recharge the aquifer directly. Near the coast, the top of the Floridan aquifer system ranges from about 200 to 500 feet below land surface and is overlain by a thick sequence of confining beds that greatly impede discharge.

Throughout the northern and central parts of northeast Florida, the upper part of the aquifer contains freshwater and the lower part contains salty water. In the vicinity of Jacksonville, the aquifer contains freshwater to a depth of about 2,000 feet. The zone of freshwater in the aquifer becomes thinner toward the south. In the vicinity of St. Augustine, the aquifer contains only salty water. Most of the municipal water supplies for St. Augustine and the adjacent coastal communities south of St. Augustine are obtained from wells about 95 feet deep in the surficial aquifer.

The city of Jacksonville and adjacent beach communities obtain all of their water from the Floridan aquifer system. Jacksonville has about 70 active municipal water supply wells that tap the aquifer. The wells range in depth from about 800 to 1,500 feet. Most of the wells are in 13 municipal well fields located throughout the city. Some wells, owned by other public utilities, are isolated and serve only specific areas of Duval County. In 1980, public utilities in Duval County pumped an average of about $60 \mathrm{Mgal} / \mathrm{d}$ to supply about 410,000 people. 


\section{Water-Management Concerns and Practices}

The Floridan aquifer system has provided ample quantities of suitable quality water to Jacksonville for many years and, if the aquifer is properly managed, will supply sufficient quantities of water for many years to come. However, increased withdrawals of water from the aquifer to meet the needs of an increasing population and expanding industry have caused some concerns about the availability of future supplies. Between 1960 and 1980, the population of Jacksonville increased about 25 percent and the municipal pumpage increased about 61 percent. Artesian pressures declined from 5 to more than 20 feet throughout the city. If the trend of water use continues, artesian pressure should continue to decline in the future.

Associated with this decline is the threat of saltwater intrusion in the aquifer. Within the past several years there has been a rise in the chloride concentration in water in some of the deeper municipal wells in the eastern part of Jacksonville and at Jacksonville Beach, which is an indication of saltwater intrusion. As yet, the increases are relatively small and are occurring in isolated areas. However, saltwater intrusion could become more pronounced and widespread as artesian pressures continue to decline.

Declines in artesian pressure and saltwater intrusion can be controlled by proper water management.

Water conservation and utilization of other sources of water, such as surface water for certain industrial and commercial users, could help reduce demands from the Floridan aquifer system and help control declines of artesian pressure. Well fields located in areas less susceptible to saltwater intrusion and to large declines in artesian pressure, can provide water to sensitive areas through a grid-distribution system. These techniques and other management practices are being examined by local and State water-management agencies.

\section{Northwest Florida (Tallahassee-Pensacola)}

\section{Source of Supplies}

Municipal water supplies in northwest Florida are obtained from three sources: the Floridan aquifer system, surface water, and the sand-and-gravel aquifer. Many of the smaller muncipalities in the eastern and central parts of northwest Florida also obtain their water supplies from the Floridan aquifer system. Towns 
such as Crestview, Fort Walton Beach, and Panama City Beach each have from 2 to more than 10 wells that tap the Floridan aquifer system. The wells range from 120 to 980 feet in depth.

Panama City and adjacent incorporated and unincorporated areas along the coast obtain surface water from Deer Point Lake Reservoir at the lower end of Econfina Creek, about $10 \mathrm{miles}$ to the north. Quincy and Port St. Joe obtain surface water from Quincy Creek and the Chipola River, respectively.

The westernmost part of northwest Florida, including Fensacola and adjacent metropolitan areas, obtains municipal supplies from the sand-and-gravel aquifer which underlies the entire western part of northwest Florida and extends west and north into Alabama. In the Pensacola area, the aquifer extends to about 300 feet below land surface. The aquifer is unconfined and is recharged by local rainfall. Unlike the Floridan aquifer system and Biscayne aquifer which are made up of soluble limestone, the sand-and-gravel aquifer consists mostly of insoluble quartz sand and the water in the aquifer contains few minerals. The hardness of the water is generally less than $10 \mathrm{mg} / \mathrm{L}$ and the dissolvedsolids concentration is less than $50 \mathrm{mg} / \mathrm{L}$. Because it contains such a small amount of dissolved solids, the water is slightly acidic and thus corrosive to pipes and plumbing fixtures. Tallahassee, in the eastern part of the area, obtains its water from the Floridan aquifer system that extends to more than 1,500 feet below 1 and surface. The city has about 20 wells that range in depth from about 300 to 500 feet. Pumpage in 1980 was about $19 \mathrm{Mgal} / \mathrm{d}$ to supply about 100,000 people. Pensacola obtains its municipal supply from about 22 wells ranging in depth from 230 to 265 feet. In 1980 , the city pumped an average of $25 \mathrm{Mgal} / \mathrm{d}$ from the sand-and-gravel aquifer to supply more than 140,000 people.

\section{Water-Management Concerns and Practices}

The sand-and-gravel aquifer can supply large quantities of freshwater to the population of northwest Florida for many years; however, there are some local problems in maintaining suitable water quality in some of the heavily populated and coastal areas. The aquifer is unconfined and is susceptible to contamination from surface sources. In some urbanized and industrial areas, seepage from sewers, septic tanks, landfills, industrial infiltration ponds, and urban runoff have 
increased the concentration of nitrate in the water in the aquifer, which is an indication of contamination. With continued urbanization and industrial development, this contamination will continue to increase unless the disposal of waste products is carefully controlled.

Another type of contamination is seawater intrusion. Many of the low-lying areas in southern Escambia and Santa Rosa Counties are subject to periodic flooding by seawater. This water can seep downward and contaminate the freshwater in the aquifer. Also, excessive pumpage from wells near bodies of saltwater have lowered the water levels and induced salty water to move laterally into the aquifer. This has occurred locally at several locations in areas of concentrated industrial and municipal pumpage. To avoid any additional saltwater intrusion, the development of large water supplies in these areas must be carefully planned and regulated.

\section{SOURCES OF ADDITIONAL INFORMATION}

Additional information on water resources can be obtained from offices of the Florida Department of Environmental Regulation in Fort Myers, Jacksonville, Orlando, Panama City, Pensacola, Tallahassee, Tampa, and West Palm Beach; Northwest Florida Water Management District, Havana; St. Johns River Water Management District, Palatka; South Florida Water Management District, West Palm Beach; Southwest Florida Water Management District, Brooksville; Suwannee River Water Management District, Live Oak; and offices of the U.S. Geological Survey in Miami, Orlando, Tallahassee, Tampa, Jacksonville, and Fort Myers.

\section{CONVERSION FACTORS}

For use of readers who prefer to use metric units, conversion factors for terms used in this report are listed below:

\begin{tabular}{|c|c|c|}
\hline $\begin{array}{l}\text { Multiply inch-pound } \\
\text { units }\end{array}$ & By & $\begin{array}{l}\text { To obtain metric } \\
\text { (SI) units }\end{array}$ \\
\hline inch (in.) & 25.4 & millimeter (mm) \\
\hline foot (ft) & 0.3048 & meter $(m)$ \\
\hline pound ( $1 b)$ & 453.6 & $\operatorname{gram}(g)$ \\
\hline mile (mi) & 1.609 & kilometer $(\mathrm{km})$ \\
\hline $\begin{array}{l}\text { square mile } \\
\left(m i^{2}\right)\end{array}$ & 2.590 & $\begin{array}{l}\text { square kilometer } \\
\left(\mathrm{km}^{2}\right)\end{array}$ \\
\hline gallon (gal) & 3.785 & liter $(L)$ \\
\hline $\begin{array}{l}\text { gallon per day } \\
(8 a 1 / d)\end{array}$ & 0.003785 & $\begin{array}{l}\underset{3}{\text { cubic meter per day }} \\
(\mathrm{m} / \mathrm{d})\end{array}$ \\
\hline $\begin{array}{l}\text { million gallons per } \\
\text { day (Mgal/d) }\end{array}$ & 0.04381 & $\begin{array}{l}\text { cubic meter }{ }_{3} \text { per } \\
\text { second }(\mathrm{m} / \mathrm{s})\end{array}$ \\
\hline
\end{tabular}




\section{SELECTED REFERENCES}

Claiborne, Maude, Nierstheimer, L. O., and Hoy, N. D., 1983, Bibliography of U.S. Geological Survey reports on the water resources of Florida, 1886-1982: U.S.

Geological Survey Open-File Report 83-540, 311 p.

Duerr, A. D., and Trommer, J. T., 1981, Estimated water use in the Southwest Florida Water Management District and adjacent areas, 1980: U.S. Geological Survey Open-File Report 81-1060, $60 \mathrm{p}$.

Franks, B. J., ed., 1982, Principal aquifers in

Florida: U.S. Geological Survey Water-Resources Investigations Open-File Report 82-255, 4 sheets.

Franks, B. J., Irwin, G. A., 1980, Chemical, physical, and radiological quality of selected public water supplies in Florida, January-May 1979: U.S. Geological Survey Water-Resources Investigations 80-13, $183 \mathrm{p}$.

Healy, H. G., 1977, Public water supplies of selected municipalities in Florida, 1975: U.S. Geological Survey Water-Resources Investigations Report 77-53, $309 \mathrm{p}$.

--- 1981, Estimated pumpage from ground-water sources for public supply and rural domestic use in Florida, 1977: Florida Bureau of Geology Map Series 102,

1 sheet.

Heath, R. C., and Conover, C. S., 1981, Hydrologic almanac of Florida: U.S. Geological Survey OpenFile Report 81-1107, $239 \mathrm{p}$.

Irwin, G. A., and Healy, H. G., 1978, Chemical and physical quality of selected public water supplies in Florida, August-September 1976: U.S. Geological Survey Water-Resources Investigations 78-21, $200 \mathrm{p}$.

Irwin, G. A., Kirkland, R. T., and Pruitt, J. B., 1985, Quality of ground water used for public supply in Florida, 1983-84: U.S. Geological Survey Open-File Report 84-804, 1 sheet.

Leach, S. D., 1982, Source, use, and disposition of water in Florida, 1980: U.S. Geological Survey Water-Resources Investigations Report 82-4090, $337 \mathrm{p}$.

---- 1984, Projected public supply and rural selfsupplied water use in Florida through year 2020: Florida Bureau of Geology Map Series 108, 1 sheet. Swayze, L. J., and Miller, W. L., 1984, Hydrogeology of a zone of secondary permeability in the surficial aquifer of eastern Palm Beach County, Florida: U.S. Geological Survey Water-Resources Investigations Report 83-4249, $39 \mathrm{p}$. 
As the Nation's principal conservation agency, the Department of the Interior has responsibility for most. of our nationally owned public lands and natural resources. This includes fostering the wisest use of our land and water resources, protecting our fish and wildlife, preserving the environmental and cultural values of our national parks and historical places, and providing for the enjoyment of life through outdoor recreation. The Department assesses our energy and mineral. resources and works to assure that their development is in the best interests of all our people. The Department also has a major responsibility for American Indian reservation communities and for people who live in Island Territories under U.S. administration.

\section{UNITED STATES DEPARTMENT OF THE INTERIOR \\ DONALD PAUL HODEL, Secretary GEOLOGICAL SURVEY \\ Dallas L. Peck, Director}
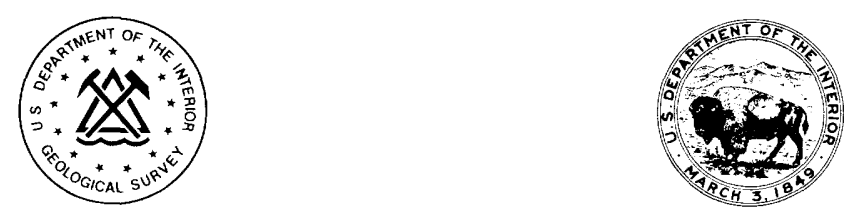

For additional information write to:

District, Chief

U.S. Geological Survey

Suite 3015

227 North Bronough St. Tallahassee, FL 32301
Copies of this report can be purchased from:

U.S. Geological Survey

Books and Open-File Reports Section

Federal Center, Bldg. 41

Box 25425

Denver, Colorado 80225

(Telephone: (303) 236-7476) 